Man and Nature

L'homme et la nature

\title{
Bürger's Münchhausen: A Text of the Body-Politic
}

\section{Arnd Bohm}

Volume 11, 1992

URI : https://id.erudit.org/iderudit/1012676ar

DOI : https://doi.org/10.7202/1012676ar

Aller au sommaire du numéro

Éditeur(s)

Canadian Society for Eighteenth-Century Studies / Société canadienne d'étude du dix-huitième siècle

ISSN

0824-3298 (imprimé)

1927-8810 (numérique)

Découvrir la revue

Citer cet article

Bohm, A. (1992). Bürger's Münchhausen: A Text of the Body-Politic. Man and Nature / L'homme et la nature, 11,111-123. https://doi.org/10.7202/1012676ar

Copyright (c) Canadian Society for Eighteenth-Century Studies / Sociéte canadienne d'étude du dix-huitième siècle, 1992
Ce document est protégé par la loi sur le droit d'auteur. L'utilisation des services d'Érudit (y compris la reproduction) est assujettie à sa politique d'utilisation que vous pouvez consulter en ligne.

https://apropos.erudit.org/fr/usagers/politique-dutilisation/ 


\section{Bürger's Münchhausen: A Text of the Body-Politic}

Gottfried August Bürger (1747-1794) is remembered primarily as the author of the ballad 'Leonore' ${ }^{1}$ and as the target of Schiller's criticism in the review 'Über Bürgers Gedichte.' ${ }^{2}$ Relatively few readers of the popular Adventures of Baron Münchhausen would associate the book with Bürger's name. ${ }^{3}$ And fewer readers still would discern, at first glance, the presence of Bürger's radical politics in that work. Nevertheless, two of the scholars most knowledgeable about Bürger concur in the perception of a political moment there. Penelope E.A.L. Scott observed:

Es ist so viel echt Bürgerisches im Text; seine politischen Interessen werden immer geschickt eingeschaltet. Er ist auf der Seite der Unterdrückten - gegen alles Autoritäre geistiger oder weltlicher Art. ${ }^{4}$

Indeed, Bürger had good reason to sympathize with the oppressed, for, like many German writers of the eighteenth century, he knew the reality of their conditions at first hand. His letters to the publisher Dieterich are filled with requests for loans and advances, as well as detailed complaints about his health and well-being. ${ }^{5}$ Often Bürger suffered from poor health due to overwork, and he died impoverished. ${ }^{6}$ In a similar vein as Scott, Günter Häntzschel has indicated that there might be more to the tall tales of Münchhausen than an aura of amusing adventure:

Wer die Abenteuer nur etwas gegen den Strich liest - und Bürger gibt dazu versteckte Hinweise - , wird bald gewahr, daß hinter den phantastischen Lügenmärchen eine Satire auf menschliche Fehler und Schwächen zu Tage tritt. Sie richtet sich vor allem gegen das Verhalten der Mächtigen und Regenten....

The problem is where to locate and recover the subtle indications of a political message in Bürger's writings.

Like his German contemporaries, Bürger was well aware of the limitations upon any free expression of discontent with the social order that gave them so little comfort. Nevertheless, Bürger did protest 
openly, as in the famous poem 'Der Bauer an seinen Fürsten,' which may be seen as one of the first modern political poems in German. Such direct voicing in public of the sufferings endured privately was consistent with Bürger's anti-idealist, non-utopian aesthetic. Fundamental to this aesthetic was an acceptance and affirmation of the body as the site where both history and art were produced. Our ability to recover the radical implications of embodied aesthetics has been enhanced by a great deal of work in the last twenty years, in a range of disciplines. ${ }^{8}$ Particularly valuable contributions have been made by art historians, for whom representation in works of art and representations by them are visibly juxtaposed. Not incidentally, the human body thereby assumes special significance as the intersection for political and aesthetic issues. Alex Potts, for example, has shown how the idealized bodies displayed in classical Greek sculpture and described by Winckelmann were re-charged with political implications in the discourses of the French Revolution. As he points out in a passage which I see as relevant also to Bürger, the gaps between ideal and actual bodies form an organizing idea in those discourses:

The ideal subjectivity signified by the ideal body, the virtue embodied in its beauty, was a public political issue in a way that it could not have been for Winckelmann. Nevertheless, the tensions inherent in the 'utopian' image of a free male subject found in Revolutionary culture are not totally distinct from those that surface in the more 'radical' moments of the late Enlightenment. ${ }^{9}$

Bürger's awareness of the centrality of the body in making the revolutions may be read straightforwardly in two of his works which were immediate responses to the events in France. While much research remains to be done on excavating precise details of Bürger's reception of the Revolution and the Germans' rejection of it, it is evident that he saw the history of revolutionary struggle as one inscribed by and through bodies. The poem 'Straflied beim schlechten Kriegsanfange der Gallier' (1793) is an unexpected poem from someone who was supposed to be 'ein Dichter des deutschen Volkes,' for it castigates the French for not having fought ruthlessly enough to have defeated the Germans. The poem is against the 'Volk,' insofar as the 'Volk' was the sublime idealization of the Germans and not the actual population which needed liberty no less than did the French peasants. Bürger's anger is directed at the French for not having put their militant bodies into battle with enough fervour: 
Wer nicht für Freiheit sterben kann

Der ist der Kette wert;

Ihn peitsche Pfaff' und Edelmann

Um seinen eignen Herd!

O Franzen, eure Rednerei

Ist mir ein Greuel nun;

Nicht prahlen, daß man tapfer sei,

Nein, tapfer muß man thun.

Zwar wissen wir, um Blut erkauft

Der Sieg sich immer nicht;

Doch daß ihr wie Gesindel lauft,

Drob zürnt mein Strafgedicht. ${ }^{10}$

The remarks made by Potts about the visual arts can serve to highlight the logic of Bürger's poem. But there is a difference: instead of the victory of well-formed and beautiful bodies of heroes, Bürger depicts a failure, one which is ascribed to bodies that had become habituated to the postures of servility. The French miss the chance to actualize the sublime triumph of the Revolution and thereby deserve only the whips and chains of unfree men. Without the underpinning of embodied deeds, the sublime conceptualization of revolutionary change remains empty ('Prahlerei'). The body, which was the origin of resistance against tyranny, ought to have had an interest in carrying the struggle to its conclusion, even at the cost of its own material existence. Bürger did not live to see the triumph of revolutionary ideals on German territory; he died in 1794. The desperation of this poem arose from the contradiction it exposed in the powerlessness of his own socially fettered body: his act consists of writing a text against the recalcitrant bodies of the rebels. The poem sets up an equivalence between the whips with which the priests and aristocrats had disciplined the bodies of the oppressed, and the text with which the poet now lashes those not strong enough to bring freedom to the Germans. However impassioned Bürger's convictions, they could not prevent the ultimate rejection of the French Revolution by the Germans.

Despite the experience of defeat, Bürger insisted that the progress of political history relied upon a combination of republican ideology with the materiality of embodied experience. The economy linking the body of the state with human bodies was most boldly discussed by Bürger in an essay on 'Die Republik England,' which appeared anonymously in 
the spring of 1793 in the Berlin Politische Annalen. The anonymity was prudent, given the political tensions at the time. The reference to the English Revolution was, as Wolfgang Friedrich has noted, a common device used by Germans for talking about politics in the $1790 \mathrm{~s} .{ }^{11}$ The essay displays Bürger's conviction that historical events had to be analyzed in material terms, based on the body as well as on ideology. He focused upon events in Ireland even though they were not central to the English Revolution, for there the extremes of violence had paved the way for the Revolution. Aware of the possible objections against the description of such matters, he underscored the importance of negative examples for the cause of the Enlightenment generally. ${ }^{12}$ The suffering caused by the text will serve as a warning, 'die Guten zu warnen, und die Bösen wo möglich zu schrecken' (Werke 4: 20). Having forewarned readers, Bürger presents a tableau of all the terror that could be unleashed in the eighteenth century against the frail body. Great depths of anger and anguish must have been distilled by him into this passage. It can stand beside the opening of Michel Foucault's Discipline and Punish for the shock it delivers in foregrounding the physical dimension of history:

Einige wurden am ganzen Leibe zerfleischt an Tuchrahmhaken aufgehänget; Einige mit Stricken um den Hals über Stock und Stein, durch Morast und Pfützen zu Tode geschleift; Einige bei den Armen aufgehänget, und alsdann zerschnitten und zerfetzt, um zu sehen, wie viele Wunden ein Engländer ertragen könnte. Manche wurden lebendig aufgeschnitten, so daß die Eingeweide auf ihre Füße herab rollten. Alle diese Grausamkeiten wurden an Kindern von jedem Alter verübt, und manche Schwangern erfuhren ein gleiches Schicksal. Kinder zwang man, ihre kranken und bejahrten Ältern zur Schlachtbank herbei zu schleppen. Manche Ungeheuer trieben die Bosheit so weit, ihren Gefangenen mit der Hoffnung des Lebens zu schmeicheln, wenn sie ihre Hände mit dem Blute ihrer nächsten Verwandten besudeln wollten. So wurden Kinder verleitet, an ihren Ältern, Weiber an ihren Männern, Mütter an ihren Kindern zu Henkern zu werden, und nach vollbrachter Unthat verloren sie dennoch ein Leben, das sie für einen so gräßlichen Preis zu erkaufen gesucht hatten. Kinder wurden in Kesseln gesotten; einige Elende lebendig geschunden; andere zu Tode gesteinigt. Manche dienten, nach ausgestochenen Augen, abgeschnittenn Ohren, Nasen, Wangen und Händen, ihren höllischen Feinden zur Augenweide. Einige wurden bis an den Hals in die Erde gegraben, und so einem langsamen Tode geweihet. (Werke 4: 21) 
As the catalogue of horrors unfolds, a revulsion takes hold in the reader against any abstract ideology which could have led to such deeds. Bürger stresses that it is this type of activity which was the target of religious fanaticism: horses and livestock were also tortured and killed. The dreaded enemy of the idea was everything corporeal. Once Bürger had written this account of slaughter into the chronicle, all the subsequent historical events could be explained. The execution of the King, not the least significant of these, seems to be only mild, almost clinical retribution: 'Sein unglückliches Haupt fiel am 30. Januar, 1649, unter dem Beile des obersten Volksgerichtes' (Werke 4:4). The understatement is striking, especially in light of the execution of Louis XVI in 1793. By using the historical antecedent, Bürger was able to offer a comment upon the revolutionary economy that sacrificed the French king on the guillotine. Regicide is presented as, at worst, a small crime when contrasted with the immense suffering undergone until then by so many victims of despotism. The economy of the text reflects the distribution of poetic justice. Readers hardly twitch at the report of the King's death but are moved by the fate of the otherwise nameless people. ${ }^{13}$ The monarch's demise comes at the beginning of the essay, demonstrating that the narration of history will continue without him and that in the republic the bodies of the commoners will become central.

Not all of Bürger's texts of the body are so disturbing. Nowhere does the interplay of embodiment and textuality manifest itself in a more complex way than in the Wunderbare Reisen zu Wasser und Lande des Freyherrn von Münchhausen. The sequences of translation and re-translations of the Münchhausen story, with their amplifications and reductions, enact through intertextual playing the strategies of subversion which are being narrated. Small wonder then that the intertextual acrobatics have posed such dizzying challenges to a philological science which must presume upon the stable, upright text. The discovery that there really had been a 'Münchhausen'- Werner R. Schweizer termed him the 'Ur-Münchhausen'14 - is deceptive. One can indeed locate Hieronymous Karl Friedrich von Münchhausen (1720-1797), the 'Lügen Baron,' and can link him with the anecdotes which were published in 1781 and 1783 in the Vade Mecum für lustige Leute by August Mylius in Berlin. But what kind of authorship is established by the link? John Carswell opts for Rudolph Erich Raspe (1737-1793) as the 'author,' that is, as the one who transformed the material from the Vade Mecum into a cohesive narrative. ${ }^{15}$ Raspe deserves to be more widely known, for he was a remarkable blend of scholar, cosmopolitan, and confidence man. These matters are relevant especially since Raspe's career began at the Univeristy of Göttingen which had as its founder none other than Gerlach Adolf von Münchhausen, a cousin of the 'Lügen Baron.' If, in 
the popular mind, the two Münchhausens are often confused, it is due in part to Raspe's opening sentence in his preface: 'Der Freyherr von Münchhausen zu Bodenwerder ohnweit Hameln an der Weser gehört zu dem edlen Geschlechte gleichen Nahmens, welches den deutschen Staaten des Königs von Großbritannien den verstobenen Premierminister und mehrere andere vornehme Beamten geschenkt hat. ${ }^{16}$ This sentence can still seem harmless, although in fact there is considerable sarcasm in the phrase 'geschenkt hat.' The next sentence takes direct aim at the pretensions of the Enlightenment, of which Göttingen and its founder were major representatives. The Münchhausen who fabulates is more rational, we are told, in advancing the cause of Enlightenment than the one who reasons:

Er ist ein Mann von den originellsten Launen; und da er vielleicht gefunden hat, wie schwer es oft hält, verschrobenen Köpfen geraden Menschenverstand einzuräsoniren, und wie leicht dagegen ein dreister Haberecht eine ganze Vesammlung zu übertäuben und aus ihren fünf Sinnen hinauszuschreyen vermag: so läßt er sich in solchen Fällen niemals auf Widerlegungen ein; sondern wendet zuerst geschickt die Unterredung auf gleichgültige Gegenstände, und dann erzählt er irgend ein Geschichtchen von seinen Reisen, Feldzügen und schnurrigen Abentheuern in einem ihm ganz eigenthümlichen Tone, der aber gerade der rechte ist, die Kunst zu lügen, oder höflicher gesagt, das lange Messer zu handhaben, aus ihrem ruhigen Schlupfwinkel hervor zu kitzeln und blank zu stellen. (Reisen 9-10)

At least then, Raspe as editor/author/translator repeats one of the Münchhausen's tall tales as a refutation of the other Münchhausen.

Raspe's version was published in English in 1785 as Munchhausen's Narrative of his Marvellous Travels and Campaigns in Russia. In 1786 there appeared a German version, without the translator's name and with London as the fictive place of publication. A second revised German version appeared in 1787. Both German versions were by Bürger, who had not only added a number of episodes but also inserted deft allusions to late eighteenth-century German conditions. ${ }^{17}$ The preface to the German edition mocks the conventions of academic learning. Without the trappings of scholarship, it is claimed, the book will be more effective: 'Denn es ist alsdann, so klein und frivol es immer scheinen mag, leicht mehr werth, als eine große Menge dickbeleibter ehrenvester Bücher, wobei man weder lachen noch weinen kann, und worin weiter nichts steht, als was in hundertmal mehr andern dickbeleibten ehrenvesten Büchern längst gestanden hat' (Reisen 13). The repetition of 'dickbeleibt' 
is noteworthy, as it underscores a connection between texts and bodies. The thin, lithe body of the Münchhausen text is poised to do what the plump established bodies are not able to accomplish. ${ }^{18}$

A semiotic signal that Münchhausen has entered an inverted world is a literal inversion of part of the text. The word 'höflich' is printed upside down in the following sentence: 'Denn man riskiert alsdann weder mit irgend einem höflichen deutschen Postmeister eine Affaire d'honneur zu bekommen, noch von seinem durstigen Postilion vor jede Schenke geschleppt zu werden' (Reisen 15). This literal inversion was also used by Bürger in his letters, where it was only one of a number of jocular and obscene devices. What has happened? Courtesy and courtliness have been overturned by a trickster-narrative. Unlike many other trickster figures, Münchhausen is a figure who reverses the social hierarchy from above, not from below, making him especially provocative. ${ }^{19}$ A major part of this reversal consists of drawing attention to the physical body and its needs. Bodies in this text feel cold, are thirsty, tired, hungry, occasionally desiring. Such bodily awareness transgressed against both the norms of aristocratic upbringing, where decorum was supposed to control physical aspects, and against the otherworldliness of the Enlightenment ideals.

However, it is this transgression alone which enables Münchhausen to empathize with other human beings, including those whose social status has left them without power. Münchhausen's first act is one of spontaneous generosity towards a wretched man who is huddling half-naked and half-frozen in the cold. Imitating the gesture of Saint Martin, he gives the man his cloak: 'Ob mir nun gleich selbst das Herz im Leibe fror, so warf ich dennoch meinen Reisemantel über ihn her' (Reisen 16). The incident is the first of the tall tales in the collection, for no such saintly aristocrats were to be found in Bürger's environment. The norm at that time, and perhaps now too, was indifference on the part of the social elite toward the physical sufferings of the poor. Both Raspe and Bürger spent most of their lives in abject poverty, waiting in vain for some miraculous act of generosity to yield them relief from their deprivation, hunger, and sickness.

Whereas in the ordinary order of the world, bodies are frail and mortal, in the reversed universe they have been granted marvellous properties. Laws of gravity can be ignored. Münchhausen can fly through the air behind a flock of ducks: 'Nun wäre bey manchem wohl guter Rath theuer gewesen. Allein ich benutzte diesen Umstand, so gut ich konnte, zu meinem Vortheil, und ruderte mich mit meinen Rockschößen nach der Gegend meiner Behausung durch die Luft' (Reisen 23-4). His body is invincible, whether he is turning a wolf inside out or has been eaten alive by a fish. And the body can be instrumentalized without being damaged, 
for instance when he strikes sparks from his forehead. The magical qualities are common to all bodies in the text, not just to those of human beings. The best example is that of the horse which has been accidentally cut in half. Münchhausen does not notice what has happened until he finds that the horse is drinking too much water and turns around (Reisen 39). The horse does not die, for it can be patched together again by a blacksmith's inventive surgery: 'Er heftete sie nehmlich mit jungen Lorbeersprößlingen, die gerade bey der Hand waren, zusammen' (Reisen 39). The wound heals and the horse's body has been phantastically improved: 'Nehmlich, die Sprossen schlugen Wurzel in seinem Leibe, wuchsen empor und wölbten eine Laube über mir, so daß ich hernach manchen ehrlichen Ritt im Schatten meiner sowohl als meines Rosses Lorbeern thun konnte' (Reisen 40). The grafting of plant material into an animal opens up the boundaries of bodily existence: the grotesque is liberating. A similar grafting occurs in the episode where Münchhausen shoots a deer with cherry pits. He later returns to find a cherry tree growing among the deer's antlers (Reisen 28). The inmixing of otherness, blurring generic categories, replicates on the level of the body the intertextual grafting represented in the bibliographical history of the Wunderbare Reisen. In certain respects, this is an eighteenth-century analogue to the twentieth-century invention of the cyborg. ${ }^{20}$ These mixings challenge the very principles of differentiation which make hierarchic systems possible and which sustain them. Insofar as the body is common to all people, class distinctions must artificially exclude the body from any crossing, lest the common ground of physical being become visible and also negotiable.

The fact that social relations are fundamentally relations worked out among bodies is represented in Münchhausen's stories about his dog and his horse. These stories are expressed in a terminology which reveals a social dimension. The dog began as a swift, long-legged greyhound. As a result of faithful service, its very body has been altered: 'Er lief so schnell, so oft und so lange in meinem Dienste, daß er sich die Beine ganz bis dicht unterm Leibe weglief, und ich ihn in seiner letzten Lebenszeit nur noch als Dachssucher gebrauchen konnte, in welcher Qualität er mir denn ebenfalls noch manch liebes Jahr diente' (Reisen 32-3). Quite simply, the body has been transformed in the process of loyal service, so that the history of the master-servant relationship can now be read even in physiognomy. The embodiment of social relations is elaborated in the anecdote which follows right after the ones about the greyhound, when Münchhausen is called upon to break in a wild horse. As the agile master of his own body, he is able to tame the horse immediately. Indeed, he exceeds all expectations and manages to bring the horse into the polite society of a tea room: 
Hier ritt ich nun verschieden male, bald Schritt, bald Trott, bald Galopp herum, setzte endlich sogar auf den Theetisch, und machte da im Kleinen überaus artig die ganze Schule durch, worüber sich denn die Damen ganz ausnehmend ergötzten. Mein Rößchen machte alles so bewundernswürdig, daß es weder Kanne noch Tassen zerbrach. (Reisen 34-5)

The introduction of the trained horse into the tea-party serves as a drastic reminder that beneath all the careful, regulated formality of a refined social event there lurk bodies. The bonds of social convention are flimsy, whether they control horses or humans.

On the other hand, it would be a mistake to see the imposition of decorum over the body as solely oppressive. There is a distinction to be made between the domination of one body over another, as in the master/servant or rider/horse situations, and the self-contol over one's own body. The self-controlled body becomes graceful, and grace leads to new possibilities of motion. One can also read the bourgeois imitation of aristocratic bearing as a critical moment of self-assertion. The 'training to walk upright' appropriated for the bourgeoisie manners and postures which challenged, through mimesis, the hegemony of privilege of courtly behavior. ${ }^{21}$ Citizens who stood, walked, and gestured as if they were aristocrats would be indistinguishable from the nobility. At various junctures this text reflects the contradictions implied by the effort to overcome the aristocracy through mimicry. The best-known is the episode where Münchhausen pulls himself and his horse out of the swamp: 'Hier hätte ich unfehlbar umkommen müssen, wenn nicht die Stärke meines eigenen Armes mich an meinem eigenen Haarzopfe, samt dem Pferde, welches ich fest zwischen meine Kniee schloß, wieder herausgezogen hätte' (Reisen 43). The body which is standing up for the first time must do the impossible: it must establish the ground upon which it will stand even while it is rising up. Once the ladder of hierarchy has been taken away, one can neither depend on superiors nor stand upon inferiors in order to establish one's position. The same theme of lifting oneself by one's own bootstraps is amplified when Münchhausen must climb down from the moon:

Mit der linken Hand hielt ich mich fest, und in der rechten führte ich meine Axt. So wie ich nun eine Strecke hinunter geglitten war, so hieb ich immer das überflüßige Stück über mir ab, und knüpfte dasselbe unten wieder an, wodurch ich denn ziemlich weit herunter gelangte. (Reisen 43)

It is also present in his quick agility in switching seats from an outgoing to an incoming cannonball. The acrobatic body should be able to liberate 
itself once it has learned to be neither master nor slave. Unfortunately, neither Bürger nor Raspe managed the trick.

The greatest threat to the established order comes when the grotesque body is also self-disciplined. In this regard there seems to be a break between the first set of adventures and the second group of adventures at sea. The main hint of the militant body in Part One is nonetheless important and must be quoted at length:

Ich hatte so heftig, so lange, so unermüdet auf den Feind losgehauen, daß mein Arm dadurch endlich in eine unwillkürliche Bewegung des Hauens gerathen war, als der Feind schon längst über alle Berge war. Um mich nun nicht selbst, oder meine Leute, die mir zu nahe kamen, für nichts und wider nichts zu prügeln, und zu Ruhe und Schlaf zu gelangen, sah ich mich genöthigt, meinen Arm an die acht Tage lang eben so gut in der Binde zu tragen, als ob er mir halb abgehauen gewesen wäre. (Reisen 40)

The passage could be discussed at length, for it touches upon the very centre of punishment and the social induction of physical self-control in the German context. Structurally, the story resembles the notorious 'Märchen vom eigensinnigen Kind. ${ }^{22}$ However, here the destabilizing potential of the grotesquely autonomous arm has been contained by Münchhausen himself. Autonomy is retained and regulated by the body even as it becomes aware of its own force. The episode of the sea adventures which displays the most extended segment of consecutive narrative presents five individuals whose bodies display a similar tension between force and restraint. The runner, the listener, the seer, the carrier, and the blower all have one superhuman ability. They are workers whose bodies have become highly specialized. Münchhausen's role now is to coordinate the activities of these bodies in order to outwit the archetypal despot, the Grand Sultan. Properly disciplined and directed, these bodies easily overwhelm the despot who has only weak bodies at his disposal-namely his own and those of loyal subordinates. What we have then is a blueprint for the revolution of the bodies against the political order. Just as Münchhausen has marshalled five phantastic bodies under the aegis of a guiding narrator's intelligence, so the multiple sources of the Wunderbare Reisen have been assembled into a profound attack upon the government of the mind.

One might ask, to what extent Bürger was aware of implications that the antagonism between body and mind might have for the political ramifications of a body-centred discourse? While much of what he wrote was a primary response to his own situation, emanating from the consciousness of the weak outsider confined to the lower rungs of the 
social ladder, he also reflected upon the production of history by bodies and texts. It would be a mistake to misread as a betrayal of the body his exhortation that students at German universities should study rhetoric:

Wenn wir Sclaven sind, so sind wir's wahrlich nicht durch jene Stein-, Eisen-, Blei- und Fleischmassen der Tyrannen, denen wir nicht ähnliche Massen entgegen zu stellen haben; sondern darum sind wir's weil wir die kraft- thatund siegreichsten Künste des Geistes, die Künste, zu reden und zu schreiben, vernachlässigen. Die Körper herrschen nicht über die Geister; sondern die Geister herrschen über die Körper. Und was sind die Evolutionen der Körper gegen die Evolutionen der Geister? (Werke 3: 405-6)

Taken out of context, this could be construed as yet another affirmation of hopeful idealism. But against the background of Bürger's voicing of the body, the important point is that a disembodied rhetoric is empty. Writing and speaking in public presupposes that citizens would already be employing their organs in the interests of emancipation. Bürger was saying no more than that the instruments available to the state - the arms and tools of the body politic - could not prevail against subjects who had learned to move about freely.

\author{
ARND BOHM \\ Carleton University
}

\title{
Notes
}

1 On Bürger's reputation, see Gert Ueding, 'Von der unheilbaren Liebe als Stimulans der Poesie: Der Dichter Gottfried August Bürger,' in his Die anderen Klassiker: Literarische Porträts aus zwei Jahrhunderten (München, 1986), 13-34; and Lore Kaim-Kloock, Gottfried August Bürger: Zum Problem der Volkstümlichkeit in der Lyrik (Berlin, 1963), 170-205. 'Lenore' also had a considerable reception in England, as documented by Evelyn B. Jolles, G.A. Bürgers Ballade 'Lenore' in England (Regensburg, 1974).

2 On the specifics of the debate between Schiller and Bürger, see Walter Hinderer, 'Schiller und Bürger: Die ästhetische Kontroverse als Paradigma,' Jahrbuch des Freien Deutschen Hochstifts (1986): 130-54; and Helmut Koopmann, 'Der Dichter als Kunstrichter: Zu Schillers Rezensionsstrategie,' Jahrbuch der Deutschen Schillergesellschaft 20 (1976): 229-46, here pp. 243-4. Rather more open to Bürger's position is Jürgen Bolten, Friedrich Schiller: Poesie, Reflexion und gesellschaftliche Selbstdeutung (München, 1985), 195-201. 
3 On the history and reception of the Münchhausen story, see Werner R. Schweizer, Münchhausen und Münchhausiaden: Werden und Schicksale einer deutsch-englischen Burleske (Bern and München, 1969); and Erwin Wackermann, Münchhausiana: Bibliographie der Münchhausen-Ausgaben und Münchhausiaden Stuttgart, 1969).

4 Penelope E.A.L. Scott, Gottfried August Bürgers Übersetzungen aus dem Englischen (Winterthur, 1964), 91.

5 Gottfried August Bürger, Mein Scharmantes Geldmännchen: Gottfried August Bürgers Briefwechsel mit seinem Verleger Dieterich, ed. Ulrich Joost (Göttingen, 1988).

6 On Bürger's life, see Günter Häntzschel, Gottfried August Bürger (München, 1988); Gerhard Kluge, 'Gottfried August Bürger,' in Deutsche Dichter des 18. Jahrhunderts: Ihr Leben und Werk, ed. Benno von Wiese (Berlin, 1977), 594-618; and Wm. A. Little, Gottfried August Bürger (New York, 1974).

7 Häntzschel, Gottfried August Bürger, 82.

8 Exemplary reference points would be Michel Foucault, Discipline and Punish: The Birth of the Prison, trans. Alan Sheridan (New York, 1979); Dorinda Outram, The Body and the French Revolution: Sex, Class and Political Culture (New Haven/ London, 1989); Elaine Scarry, The Body in Pain: The Making and Unmaking of the World (New York/ Oxford, 1985); John O'Neill, Five Bodies: The Human Shape of Modern Society (Ithaca/London, 1985); and Carol Houlihan Flynn, The Body in Swift and Defoe (Cambridge/New York, 1990). The German discussion, here in connection primarily with the 18 th century, may be charted via Erika Fischer-Lichte, 'Theatre and the Civilizing Process: An Approach to the History of Acting,' in Interpreting the Theatrical Past: Essays in the Historiography of Performance, ed. Thomas Postlewait and Bruce A. McConachie (Iowa City, 1989): 19-36; Hans Ulrich Gumbrecht, "'Mens Sana" und "Körperloses Spiel" /"Sinnloses Treten" und "In Corpore Sano,"' Sprache im technischen Zeitalter 92 (December 1984): 262-78; Utz Jaeggle, 'Im Schatten des Körpers: Vorüberlegungen zu einer Volkskunde der Körperlichkeit,' Zeitschrift für Volkskunde 76.2 (1980): 169-88; Wolfgang Kemp, 'Die Beredsamkeit des Leibes: Körpersprache als künstlerisches und gesellschaftliches Problem der bürgerlichen Emanzipation,' Städel-Jahrbuch NF 5 (1975): 111-34; and Gert Mattenklott, 'Körperpolitik oder das Schwinden der Sinne,' in 'Postmoderne' oder Der Kampf um die Zukunft: Die Kontroverse in Wissenschaft, Kunst und Gesellschaft, ed. Peter Kemper (Frankfurt a.M., 1988), 231-52.

9 Alex Potts, 'Beautiful Bodies and Dying Heroes: Images of Ideal Manhood in the French Revolution,' History Workshop Nr. 30 (1990): 1-21, here p. 14.

10 Johann Gottfried Bürger, Bürgers Gedichte in zwei Teilen, ed. Ernst Consentius (Berlin and Leizpig, [1914]), 2:148.

11 Wolfgang Friedrich, 'Zu Gottfried August Bürgers Aufsatz "Die Republik England",' Weimarer Beiträge 2 (1956): 214-32, here p. 220.

12 Gottfried August Bürger, Sämmtliche Werke (Göttingen, 1844), 4: 19-20: 'Allein ein würdiger und großer Zweck gebeut ihr [der Geschichte], diesen allgemeinen zu flachen Umriß jener Mordscenen noch mit einigen Pinselstrichen zu erheben. Das Ungeheuer, welches solche Unthaten in Irland, wie in so vielen andern Ländern des Erdbodens gebar, ist heute noch keinesweges gänzlich vernichtet, sondern von der Fackel der Vernunft nur in das Dunkel seiner Höhle zurück gescheucht.' Quotations from this edition will be cited parenthetically as Werke with volume and page numbers. 
13 A point missed by Little, Gottfried August Bürger, who saw in the essay 'a bizarre and grotesque quality' and noted that 'The trial and execution of Charles I are barely accorded a word ... although the author lingers for eight pages over the atrocities committed at the massacre of the English colonists....' (204-5).

14 Schweizer, Münchhausen und Münchhausiaden, 13.

15 John Carswell, 'Introduction,' to The Singular Adventures of Baron Munchhausen, by Rudolf Raspe (New York, 1952).

16 Gottfried August Bürger, Wunderbare Reisen zu Wasser und Lande des Freyherrn von Münchhausen, ed. Wolfgang Würfel (Darmstadt, 1959), 9. Quotations from this edition will be cited parenthetically as Reisen, with a page number.

17 Scott, Gottfried August Bürgers Übersetzungen aus dem Englischen, 78-92.

18 The influential model in the eighteenth century for the game of body = text was provided by Swift's Battle of the Books. The history of this equivalence, down to William Gass, remains to be written.

19 On the inversion of the world and the revelation of the body, see Mikhail Bakhtin, Rabelais and His World, transl. Helene Iswolsky (Bloomington, 1984); Klaus-Peter Koepping, 'Absurdity and Hidden Truth: Cunning, Intelligence and Grotesque Body Images as Manifestations of the Trickster,' History of Religions 24 (1984-85): 191-214; and Barbara A. Babcock, 'Arrange Me into Disorder: Fragments and Reflections on Ritual Clowning,' in Rite, Drama, Festival, Spectacle: Rehearsals Toward a Theory of Cultural Performance, ed. John J. MacAloon (Philadelphia, 1984), 102-28.

20 See Donna Haraway, 'A Manifesto for Cyborgs: Science, Technology, and Socialist Feminism in the 1980's,' Socialist Review 80 (1985): 65-107.

21 The emancipatory dimension is stressed by Bernd Jürgen Warncken, 'Bürgerliche Emanzipation und aufrechter Gang: Zur Geschichte eines Haltungsideals,' Das Argument 179 (1990): 39-52.

22 Oskar Negt and Alexander Kluge, Geschichte und Eigensinn: Geschichtliche Organisation der Arbeitsvermögen (Frankfurt a.M., 1981), 765-9. 